\title{
False aneurysms after heart valve surgery
}

\author{
Tirone E. David, MD
}

\footnotetext{
From the Division of Cardiac Surgery of the Peter Munk Cardiac Centre at Toronto General Hospital and the University of Toronto, Toronto, Ontario, Canada.

Disclosures: Author has nothing to disclose with regard to commercial support.

Received for publication Sept 13, 2016; accepted for publication Sept 14, 2016; available ahead of print Oct 15 , 2016.

Address for reprints: Tirone E. David, MD, 200 Elizabeth St 4N453, Toronto, Ontario M5G 2C4, Canada (E-mail: tirone.david@uhn.ca).

J Thorac Cardiovasc Surg 2017;153:51-2

$0022-5223 / \$ 36.00$

Copyright (c) 2016 by The American Association for Thoracic Surgery

http://dx.doi.org/10.1016/j.jtcvs.2016.09.019
}

In this issue of the Journal, Chenier and colleagues ${ }^{1}$ from the Cleveland Clinic reviewed their experience with 114 patients who had aortic root or ascending aortic false aneurysm develop after aortic or mitral valve repair or replacement, isolated or combined with replacement of the ascending aorta. Some of their patients may have had aortic root replacement. There were not any patients with false aneurysm of the posterior mitral annulus in this series (a complication of mitral valve replacement that is due either to spontaneous delayed rupture of the atrioventricular junction or to infective endocarditis). The false aneurysm was associated with endocarditis in only 31 patients. For some reason that is not made clear to the reader, Chenier and colleagues ${ }^{1}$ decided to report on a composite end point that included death or permanent stroke instead of death and all potential complications associated with this type of disorder, such as stroke, myocardial infarction, recurrent false aneurysm after reoperation, and so on. The false aneurysm was surgically treated in 92 patients, with a composite end point (death and/or stroke) of $14 \%$ at 1 year, which is not surprising after complex reoperative aortic root operations, particularly if the aortoventricular junction is destroyed or the mitral valve needs replacement as well. The remaining 22 patients were not operated on in 10 patients because the false aneurysm was small and stable (all did well) and in 12 patients because it was deemed inoperable (all died). The freedoms from the combined end point at 5 and 10 years were $74 \%$ and $55 \%$, respectively. When all patients were examined together, Chenier and colleagues ${ }^{1}$ found that false aneurysm associated with infection and high additive euroSCORE were independent predictors of poor outcome and that surgery was associated with improved outcome.

I don't believe that I learned much by reading this study. Actually, as I read it more questions than answers came to mind. I have seen many patients with false aneurysms after aortic and mitral valve replacement as well as after replacement of the aortic root with valved conduits, but the in vast majority of cases the false aneurysms were associated with infective endocarditis. ${ }^{2}$ In some of my

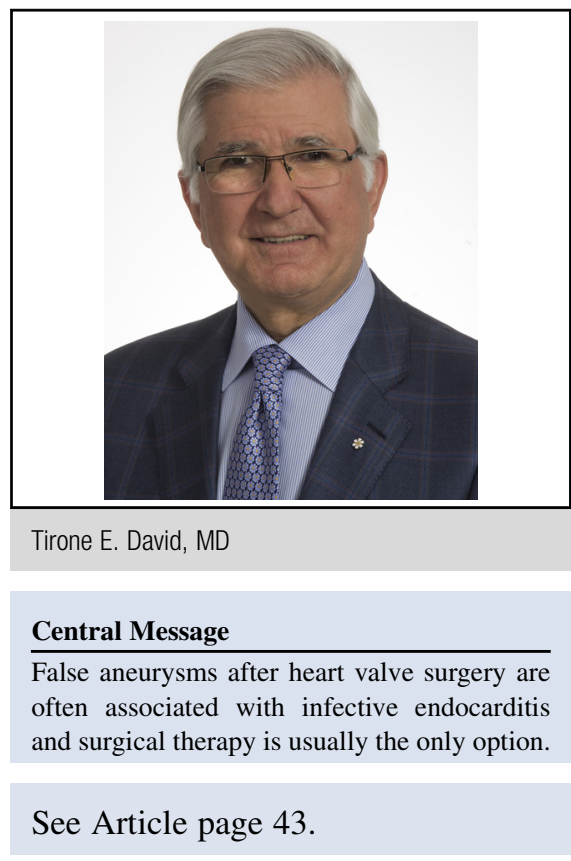

patients, the infective process disrupted the atrioventricular junction, creating a posterior mitral annulus false aneurysm. ${ }^{2}$ I have also reoperated on a couple of patients who had mitral valve replacement with delayed rupture of the posterior wall and development of a false aneurysm. Another situation that I have treated a number of times is false aneurysms secondary to disruption of the anastomosis between ascending aorta Dacron polyester fabric graft and the aortic root after surgery for acute type A aortic dissection. These cases are not associated with infection, and the false aneurysm is likely due to necrosis of the dissected aorta. The use of BioGlue (CryoLife Inc, Kennesaw, $\mathrm{Ga}$ ) may reduce intraoperative bleeding and make surgery for acute type A aortic dissection safer, ${ }^{3}$ but it also increases the risk of anastomotic false aneurysms. ${ }^{4}$

It is surprising that a center as large as the Cleveland Clinic encountered only 114 patients with false aneurysms from 1986 through 2013. I believe that Chenier and colleagues $^{1}$ would have had many more if they had reviewed all cases of aortic valve endocarditis and infected ascending aortic grafts. False aneurysms associated with prosthetic valve endocarditis are common and associated with high mortality. Surgical treatment remains challenging, and as noted by various authors, the presence of infection changes the game to a more serious one than simple repair of a disrupted arterial anastomosis. Extensive resection of infected tissues and reconstruction with various 
types of patch materials are often necessary. ${ }^{5,6}$ When reimplantation of the coronary arteries is needed, every effort should be made to use the button technique. Sometimes the interposition graft between the coronary artery and the aortic graft may facilitate the operation, however, and it is probably safer than the Cabrol technique, in which a single 8-mm Dacron polyester fabric graft is anastomosed to both coronary arteries in an end-to-end fashion and then to the aortic graft in side-to side fashion. ${ }^{7}$

Chenier and colleagues ${ }^{1}$ have raised an important issue in cardiovascular surgery. Their study demonstrates the importance of continuous surveillance of patients after heart valve surgery, with periodic physical examinations and imaging of the heart valves and great vessels.

\section{References}

1. Chenier M, Patel K, Svensson LG, Navia J, Sabik JF III, Rodriguez LL, et al. Characteristics and outcomes of patients with postoperative cardiovascular pseudoaneurysms. J Thorac Cardiovasc Surg. 2017;153:43-50.

2. David TE, Regesta T, Gavra G, Armstrong S, Maganti MD. Surgical treatment of paravalvular abscess: long-term results. Eur J Cardiothorac Surg. 2007;31: 43-8.

3. Suzuki S, Masuda M, Imoto K. The use of surgical glue in acute type A aortic dissection. Gen Thorac Cardiovasc Surg. 2014;62:207-13. Erratum in: Gen Thorac Cardiovasc Surg. 2014;62:214.

4. Luk A, David TE, Butany J. Complications of Bioglue postsurgery for aortic dissections and aortic valve replacement. J Clin Pathol. 2012;65:1008-12.

5. Sheikh AM, Elhenawy AM, Maganti M, Armstrong S, David TE, Feindel CM. Outcomes of double valve surgery for active infective endocarditis. $J$ Thorac Cardiovasc Surg. 2009; 138:69-75.

6. Krasopoulos G, David TE, Armstrong S. Custom-tailored valved conduit for complex aortic root disease. J Thorac Cardiovasc Surg. 2008;135:3-7.

7. Bachet J, Termignon JL, Goudot B, Dreyfus G, Piquois A, Brodaty D, et al. Aortic root replacement with a composite graft. Factors influencing immediate and long-term results. Eur J Cardiothorac Surg. 1996;10:207-13. 